\title{
Campylobacter nitrofigilis sp. nov., a Nitrogen-Fixing Bacterium Associated with Roots of Spartina alterniflora Loisel
}

\author{
C. R. MCCLUNG,${ }^{1} \dagger$ D. G. PATRIQUIN,${ }^{2}$ AND R. E. DAVIS ${ }^{1 *}$ \\ Plant Virology Laboratory, Plant Protection Institute, U.S. Department of Agriculture, Agricultural Research \\ Service, Beltsville Agricultural Research Center-West, Beltsville, Maryland $20705^{1}$ and Biology Department, \\ Dalhousie University, Halifax, Nova Scotia, Canada B3H $4 \mathrm{JI}^{2}$
}

\begin{abstract}
Obligately microaerophilic, nitrogen-fixing bacteria were found associated with roots of Spartina alterniflora Loisel and in root-associated sediments from salt marshes in Nova Scotia, Canada, and Georgia. These bacteria differ from previously described species and thus represent a new species. The cells of all strains which we studied are small, rigid, curved, motile, and rod shaped and have single polar flagella. Metabolism is respiratory, and the strains utilize organic and amino acids, but not carbohydrates, as sole carbon sources. Poly- $\beta$-hydroxybutyrate is not produced. These traits and the guanine-plus-cytosine contents of the deoxyribonucleic acids of these strains $(28.3 \pm 0.1 \mathrm{~mol} \%)$ indicate that they are members of the genus Campylobacter Sebald and Véron 1963. However, these strains can be distinguished from the previously described species of Campylobacter by the presence of nitrogenase, by their tolerance of and apparent requirement for $\mathrm{NaCl}$, by the production of pigment from tryptophan, by a combination of other biochemical traits, and by their association with plant roots. Therefore, we propose that these strains represent a new species, Campylobacter nitrofigilis, and we designate strain CI (= ATCC 33309) as the type strain.
\end{abstract}

Campylobacter species are commonly occurring pathogens and commensal organisms that are associated with a diverse range of animal hosts $(23,24,31)$. Of particular interest in this genus is the Campylobacter jejuni-Campylobacter coli group (Campylobacter fetus subsp. jejuni), which increasingly is being recognized as a cause of enteritis in humans $(3,10)$. In addition to the human- and animal-associated campylobacters, free-living strains of Campylobacter have been isolated in culture $(11,15)$, but the taxonomic status of these organisms has not been established yet. One of the free-living strains, strain $\mathrm{CI}^{\mathrm{T}}$ (type strain), was found associated with the roots of Spartina alterniflora Loisel growing in a salt marsh near Halifax, Nova Scotia, Canada; this strain was found to be capable of fixing nitrogen (15). In this paper we describe the isolation in culture of several additional nitrogen-fixing Campylobacter strains from $S$. alterniflora roots and root-associated sediments from a salt marsh on Sapelo Island, Georgia. We propose that these nitrogen-fixing,

$\dagger$ Present address: Department of Microbiology and Public Health, Michigan State University, East Lansing, MI 48824.
Spartina-associated strains represent a new species, Campylobacter nitrofigilis.

\section{MATERIALS AND METHODS}

Isolation. Roots of $S$. alterniflora Loisel were taken from a salt marsh on Sapelo Island, Georgia, and were washed free of sediment in adjacent creek water. Root pieces (length, $2 \mathrm{~cm}$ ) were placed in tubes of semisolid diazotroph medium (15). Other tubes were seeded with root-associated sediment samples. After $72 \mathrm{~h}$ at room temperature, the cultures were transferred to fresh tubes of semisolid malate-salts (MS) medium (15), and nitrogenase activity was determined by acetylene reduction assays (4). After $24 \mathrm{~h}$, tubes of MS medium were capped with serum stoppers, and acetylene was injected to give a final partial pressure of $\mathrm{C}_{2} \mathrm{H}_{2}$ of 2 $\mathrm{kPa}$. Acetylene reduction was measured by gas chromatography, using a Shimadzu model GC-4BM instrument equipped with a flame ionization detector and a stainless steel column $(0.32$ by $50 \mathrm{~cm})$ packed with 80 to 100 -mesh Porapak $\mathrm{T}$ at $50^{\circ} \mathrm{C}$.

Cultures that were positive for acetylene reduction were used to seed plates of molten, cooled $\left(45^{\circ} \mathrm{C}\right) \mathrm{MS}$ medium containing $7 \mathrm{~g}$ of agar per liter (27), which were incubated at $25^{\circ} \mathrm{C}$. The small, white, irregularly shaped colonies which developed were transferred to tubes of semisolid MS medium, and the resulting cultures were tested for nitrogenase activity. Nitrogenase-positive cultures were streaked onto marine agar plates which were incubated under reduced oxy- 
gen tension (partial pressure of $\mathrm{O}_{2}$, approximately 5 $\mathrm{kPa}$ ) at $25^{\circ} \mathrm{C}$. Individual colonies that formed were tested for nitrogenase activity in semisolid MS medium. Nitrogenase-positive cultures were streaked twice in succession. The pure cultures were maintained by weekly transfer in semisolid MS medium at $25^{\circ} \mathrm{C}$. Young (24- to 48-h) cultures grown in MS medium were also frozen and stored at $-70^{\circ} \mathrm{C}$ until they were needed. The Marine agar which we used had the following composition: peptone, $2.5 \mathrm{~g}$; yeast extract, $0.5 \mathrm{~g} ; \mathrm{FePO}_{4}, 0.05 \mathrm{~g}$; $\mathrm{NaCl}, 15.0 \mathrm{~g}$; agar, $15.0 \mathrm{~g}$; and distilled water, $1,000 \mathrm{ml}$. The $\mathrm{pH}$ of this medium was adjusted to 7.0 before autoclaving.

Physiological tests. Physiological tests were performed as described by Hylemon et al. (7), with the following exceptions. MS medium was used instead of a succinate-based medium. Unless otherwise indicated, all of the media used contained $15.0 \mathrm{~g}$ of $\mathrm{NaCl}$ per liter and $1.75 \mathrm{~g}$ of agar per liter. Cultures grown in liquid medium or on solid medium (15 of agar per liter) were incubated in GasPak anaerobic chambers (BBL Microbiology Systems) under reduced oxygen tensions produced with a Campypak II gas-generating envelope (BBL). All cultures were incubated at $30^{\circ} \mathrm{C}$ unless indicated otherwise.

Compounds which could serve as sole carbon sources were determined as described by McClung and Patriquin (15). Acidic reactions in tests with carbohydrates were determined in $\mathrm{O} / \mathrm{F}$ basal medium (Difco Laboratories). The carbohydrates tested were sterilized by filtration and were incorporated into media at concentrations of $10.0 \mathrm{~g} /$ /iter. Production of acid or neutral end products from glucose was tested in MRVP broth (Difco). Hippurate hydrolysis was determined by the method of Hwang and Ederer (6). Urease activity was also tested on Christiensen urease agar (1). Reduction of $\mathrm{NO}_{3}$ and $\mathrm{N}_{2} \mathrm{O}$ and growth in the presence of 2,3,5-triphenyltetrazolium chloride were determined as described by McClung and Patriquin (15). The effect of nitrate on nitrogenase activity was determined in MS medium supplemented with $\mathrm{NaNO}_{3}$ at a concentration of $1.0 \mathrm{~g} /$ liter. The effects of nitrate, aspartate, and fumarate on anaerobic growth were tested on plates of yeast extract-peptone medium in GasPak anaerobic chambers (BBL) containing a GasPak $\mathrm{H}_{2}-\mathrm{CO}_{2}$-generating envelope (BBL). Yeast extract-peptone medium contained $1.0 \mathrm{~g}$ of yeast extract, $5.0 \mathrm{~g}$ of peptone, $15.0 \mathrm{~g}$ of $\mathrm{NaCl}, 15.0 \mathrm{~g}$ of agar, and $1,000 \mathrm{ml}$ of distilled water; the $\mathrm{pH}$ was adjusted to 7.0 before autoclaving. Yeast extract-peptone medium was supplemented with $\mathrm{NaNO}_{3}$, aspartate, or fumarate at a final concentration of $2.0 \mathrm{~g} / \mathrm{liter}$. Swarming and production of coccal forms were determined as described by Karmali et al. (9), except that nutrient agar was used instead of blood agar. Nutrient agar contained (per liter of distilled water) $5.0 \mathrm{~g}$ of meat extract, $3.0 \mathrm{~g}$ of peptone, $15.0 \mathrm{~g}$ of $\mathrm{NaCl}$, and $15.0 \mathrm{~g}$ of agar; the $\mathrm{pH}$ was adjusted to 7.0 before autoclaving.

The ability of $\mathrm{KCl}$ or sucrose to replace the requirement of $\mathrm{NaCl}$ for growth was determined in nutrient broth (BBL). The broth was supplemented with $\mathrm{NaCl}$ at a concentration of $86 \mathrm{mM}(5.0 \mathrm{~g} /$ liter $)$ or $257 \mathrm{mM}$ $(15.0 \mathrm{~g} /$ liter $)$, with 86 or $257 \mathrm{mM} \mathrm{KCl}$, or with 172 or $514 \mathrm{mM}$ sucrose. Unsupplemented nutrient broth was used as a control. The osmolarities of the media were estimated by using an Advanced Instruments model $3 \mathrm{~W}$ osmometer.
To determine the presence of intracellular poly- $\beta$ hydroxybutyrate, late-log-phase cultures grown in nutrient broth (BBL) were extracted with commercial bleach and then with chloroform. Poly- $\beta$-hydroxybutyrate was measured by the crotonic acid method (12). Azospirillum lipoferum SP59b was used as a positive control for poly- $\beta$-hydroxybutyrate production.

Susceptibilities to antibiotics were assessed by disk growth inhibition tests. Plates of nutrient agar were seeded to produce bacterial lawns, and antibiotics were applied in impregnated paper disks (Difco). The plates were examined after $72 \mathrm{~h}$ for the presence of zones of inhibition around the disks. Minimal inhibitory concentrations of selected antibiotics were determined in semisolid MS medium. Susceptibility to 2,4diamino-6,7-diisopropylpteridine (vibriostatic agent 0/129; Sigma Chemical Co.) was determined in semisolid MS medium.

Cells from late-log-phase cultures grown in liquid MS medium at $30^{\circ} \mathrm{C}$ were negatively stained with $1.0 \%$ (wt/vol) potassium phosphotungstate $(\mathrm{pH} 7.0)$ and observed with a JEOL model JEM-100B transmission electron microscope.

Deoxyribonucleic acids (DNAs) were extracted and purified by the method of Lee and Davis (13). The base composition of each DNA was estimated based on thermal denaturation in $10 \mathrm{mM}$ potassium phosphate-1 $\mathrm{mM}$ ethylenediaminetetraacetate $(\mathrm{pH} \mathrm{7.0)}$ by using a model 2400 spectrophotometer (Gilford Instrument Laboratories, Inc.) equipped with a temperature programmer. Spiroplasma sp. strain PPS1 and Spiroplasma citri Maroc R8A2 were used as standards. The guanine-plus-cytosine $(\mathrm{G}+\mathrm{C})$ contents were calculated by the method of Marmur and Doty (14), assuming that the $\mathrm{G}+\mathrm{C}$ content of Spiroplasma sp. strain PPS1 DNA is $29 \mathrm{~mol} \%(15 \mathrm{~b})$ and the $\mathrm{G}+\mathrm{C}$ of $S$. citri DNA is 26 $\mathrm{mol} \%(8,19)$.

Strains of the C. jejuni-C. coli group were tested for nitrogenase activity in MS medium (with the $\mathrm{NaCl}$ concentration reduced to $5.0 \mathrm{~g} / \mathrm{liter}$ ) by using the procedures described above.

\section{RESULTS}

Nitrogen-fixing strains of Campylobacter were readily isolated from roots of both short and tall $S$. alterniflora plants and from rootassociated sediments in a salt marsh on Sapelo Island, Georgia (Table 1). Like the previously described nitrogen-fixing, Spartina-associated Campylobacter strains (15), the Georgia isolates were all gram-negative, slender, rigid, curved, rod-shaped organisms whose cells were 0.2 to $0.9 \mu \mathrm{m}$ wide by 1 to $3 \mu \mathrm{m}$ long and had single polar flagella (Fig. 1) and a characteristic rapid, corkscrew motility. Very few long, helical cells were observed.

All of these nitrogen-fixing Campylobacter strains from Georgia were positive for the following traits: nitrogenase, catalase, oxidase, $\mathrm{H}_{2} \mathrm{~S}$ production from cysteine, and production of pigment from tryptophan. All strains were capable of growth in media containing 0.5 to $7.0 \% \mathrm{NaCl}$, and all strains were able to utilize 
TABLE 1. Strains used in this study

\begin{tabular}{|c|c|c|c|c|}
\hline $\begin{array}{l}\text { Strain no. } \\
\text { in this } \\
\text { study }\end{array}$ & Name & $\begin{array}{c}\text { Original } \\
\text { strain } \\
\text { designation }\end{array}$ & Isolated from: & $\begin{array}{l}\text { Refer- } \\
\text { ence(s) }\end{array}$ \\
\hline $1^{\mathrm{T}}$ & Campylobacter sp. & $\mathrm{CI}^{\mathrm{T}}$ & $\begin{array}{l}\text { Roots of short } S \text {. alterniflora, Hali- } \\
\text { fax, Nova Scotia, Canada }\end{array}$ & 15 \\
\hline 2 & Original isolate & G1 & $\begin{array}{l}\text { Sediment from zone of short } S \text {. } \\
\text { alterniflora, Sapelo Island, } \\
\text { Georgia }\end{array}$ & \\
\hline 3 & Original isolate & G4B & $\begin{array}{l}\text { Sediment from zone of short } S \text {. } \\
\text { alterniflora, Sapelo Island, } \\
\text { Georgia }\end{array}$ & \\
\hline 4 & Original isolate & G12 & $\begin{array}{l}\text { Sediment from zone of short } S \text {. } \\
\text { alterniflora, Sapelo Island, } \\
\text { Georgia }\end{array}$ & \\
\hline 5 & Original isolate & G14 & $\begin{array}{l}\text { Sediment from zone of short } S \text {. } \\
\text { alterniflora, Sapelo Island, } \\
\text { Georgia }\end{array}$ & \\
\hline 6 & Original isolate & $\mathrm{G} 2$ & $\begin{array}{l}\text { Roots of short } S \text {. alterniflora, } \\
\text { Sapelo Island, Georgia }\end{array}$ & \\
\hline 7 & Original isolate & G10 & $\begin{array}{l}\text { Roots of tall } S \text {. alterniflora, Sapelo } \\
\text { Island, Georgia }\end{array}$ & \\
\hline 8 & Original isolate & G3 & $\begin{array}{l}\text { Roots of tall } S \text {, alterniflora, Sapelo } \\
\text { Island, Georgia }\end{array}$ & \\
\hline 9 & Original isolate & G5 & $\begin{array}{l}\text { Roots of tall } S \text {. alterniflora, Sapelo } \\
\text { Island, Georgia }\end{array}$ & \\
\hline 10 & Original isolate & G6 & $\begin{array}{l}\text { Roots of tall } S \text {. alterniflora, Sapelo } \\
\text { Island, Georgia }\end{array}$ & \\
\hline 11 & Original isolate & G9 & $\begin{array}{l}\text { Roots of tall } S \text {. alterniflora, Sapelo } \\
\text { Island, Georgia }\end{array}$ & \\
\hline 12 & Original isolate & G13 & $\begin{array}{l}\text { Roots of tall } S \text {. alterniflora, Sapelo } \\
\text { Island, Georgia }\end{array}$ & \\
\hline 13 & $\begin{array}{l}\text { C. jejuni-C. coli group }(C . \text { fetus } \\
\text { subsp. jejuni ATCC } 29428)^{a}\end{array}$ & $\mathrm{H} 840$ & Diarrheic stool of child & \\
\hline $14-33$ & C. jejuni-C. coli group ${ }^{b}$ & & Beef, pork, and lamb carcasses & 25,26 \\
\hline $34-42$ & C. jejuni-C. coli group ${ }^{c}$ & & Cases of human gastroenteritis & \\
\hline 43 & Spiroplasma citri & $\begin{array}{l}\text { Maroc } \\
\text { R8A2 }\end{array}$ & Citrus cinensis & 19 \\
\hline 44 & $\begin{array}{l}\text { Spiroplasma sp. strain ATCC } \\
2^{27556^{d}}\end{array}$ & PPS1 & Calliandra haematocephala & 16 \\
\hline 45 & Azospirillum lipoferum ${ }^{e}$ & SP59b & Wheat roots, Rio de Janeiro, Brazil & 29 \\
\hline
\end{tabular}

a ATCC, American Type Culture Collection, Rockville, Md.

${ }^{b}$ Obtained from N. J. Stern, Meat Science Research Laboratory, Animal Science Institute, U.S. Department of Agriculture, Agricultural Research Service, Beltsville Agricultural Research Center-East, Beltsville, Md.

'Obtained from J. C. Coolbaugh, Naval Medical Research Institute, Bethesda, Md.

${ }^{d}$ Obtained from R. E. McCoy, Agricultural Research Center, University of Florida, Fort Lauderdale.

e Obtained from P. van Berkum, Cell Culture and Nitrogen Fixation Laboratory, Plant Physiology Institute, U.S. Department of Agriculture, Agricultural Research Service, Beltsville Agricultural Research Center-West, Beltsville, Md.

the following compounds as sole carbon and energy sources: L-asparagine, L-aspartate, fumarate, L-glutamate, L-glutamine, $\alpha$-ketoglutarate, lactate, malate, L-proline, pyruvate, and succinate. All of these nitrogen-fixing Campylobacter strains were negative for the following traits: Gram reaction, phosphatase, sulfatase, indole production, nitrite reduction, methyl red test, Voges-Proskauer test, fluorescent pigment production, production of pigment from phenylalanine or tyrosine, production of poly- $\beta$-hydroxybutyrate, swarming on moist media, and rapid coccal transformation. None of the strains was capable of growth at $42^{\circ} \mathrm{C}$, growth in media containing $1.0 \%$ glycine or $0.1 \% 2,3,5$-triphenyltetrazolium chloride, or growth in media containing $0.01 \% \mathrm{NaCl}$. None of the strains was able to hydrolyze esculin, DNA, gelatin, hippurate, or soluble starch. No strain produced an acid reaction from carbohydrates (arabinose, fructose, glucose, inositol, lactose, mannose, mannitol, sorbitol, sucrose, and xylose), and no strain was able to utilize the following compounds as sole sources of carbon and energy: $\beta$ alanine, L-arginine, citrate, L-cysteine, malonate, L-arabinose, D-fructose, D-glucose, $i$ - 


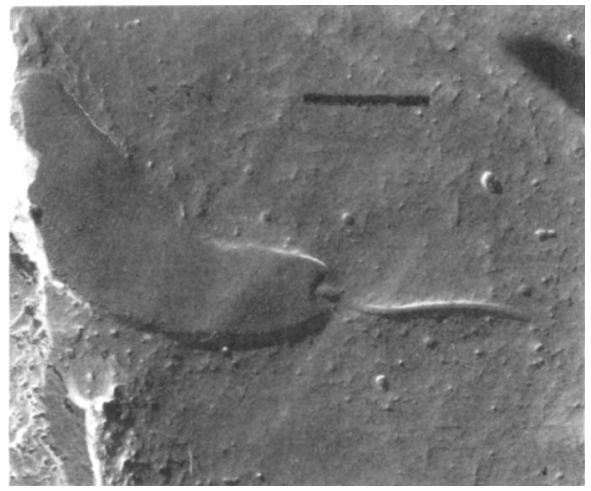

FIG. 1. Electron micrograph of freeze-etched $C$. nitrofigilis ATCC $33309^{\mathrm{T}}$ cell. Bar $=0.5 \mu \mathrm{m}$. Photo courtesy of C. Bean and R. L. Steere.

inositol, lactose, D-mannose, D-mannitol, Dsorbose, sucrose, and D-xylose.

The biochemical and physiological characteristics of the nitrogen-fixing Campylobacter strains for which we observed differences among strains are shown in Table 2. In all strains growth was usually obligately microaerophilic, with only very weak growth detected under anaerobic conditions. However, anaerobic growth on plates containing MS medium or nutrient agar was greatly stimulated by adding either aspartate or fumarate. Nitrate did not stimulate anaerobic growth and prevented the stimulation of anaerobic growth by aspartate and fumarate in all strains except strains 4 and 5
(Table 2). Strains 4 and 5 both lacked dissimilatory nitrate reductase activity, in contrast to all other strains, which did reduce nitrate to nitrite. Nitrite was not further reduced. Nitrate $(1.0$ $\mathrm{g} /$ liter) suppressed nitrogenase activity by all strains except strains 4 and 5 . On the basis of thermal denaturation, the $\mathrm{G}+\mathrm{C}$ contents of the DNAs of the nitrogen-fixing Campylobacter strains were estimated to be $28.3 \pm 0.1 \mathrm{~mol} \%$.

The responses of the Campylobacter strains to several antibiotics are shown in Table 3. The antibiotic susceptibilities of these strains were generally consistent with those reported for other members of the genus $(24,30)$. Certain antibiotics may be useful in species differentiation (Table 4) (31).

All strains of the $C$. jejuni-C. coli group examined grew well in MS medium, but were nitrogenase negative.

\section{DISCUSSION}

The nitrogen-fixing strains which we studied were judged to be affiliated with the Spirillaceae on the basis of their Gram reactions, motility, and growth as rigid, curved rods with strictly respiratory metabolism. The presence of a single polar flagellum, the lack of poly- $\beta$-hydroxybutyrate production, and the DNA base composition $(28.3 \pm 0.1 \mathrm{~mol} \% \mathrm{G}+\mathrm{C})$ indicate these strains should be placed in the genus Campylobacter. This placement in Campylobacter was confirmed by the physiological and biochemical characteristics of the strains, which in general are consistent with those of previously de-

TABLE 2. Biochemical characteristics of $C$. nitrofigilis for which there are strain differences

\begin{tabular}{|c|c|c|c|}
\hline Characteristic & $\begin{array}{c}\text { No. of strains } \\
\text { positive } /(n=12)\end{array}$ & $\begin{array}{l}\text { Reaction of } \\
\text { type strain } 1\end{array}$ & $\begin{array}{l}\text { Strain(s) that gave } \\
\text { the less common } \\
\text { result }\end{array}$ \\
\hline Urease (Hylemon et al.) ${ }^{a}$ & 10 & + & 2,3 \\
\hline Urease $\left.^{(C h r i s t e n s e n}\right)^{b}$ & 5 & + & $1^{\mathrm{T}}, 6,7,9,12$ \\
\hline Nitrate reduction & 10 & + & 4,5 \\
\hline Growth with $1.0 \%$ bile & 9 & - & $1^{\mathrm{T}}, 2,3$ \\
\hline \multicolumn{4}{|l|}{ Anaerobic growth with: } \\
\hline Aspartate + nitrate & 2 & - & 4,5 \\
\hline Fumarate + nitrate & 2 & - & 4,5 \\
\hline Growth at $6^{\circ} \mathrm{C}$ & 6 & + & $1^{\mathrm{T}}, 3,7,8,11,12^{\mathrm{c}}$ \\
\hline Growth at $37^{\circ} \mathrm{C}$ & 11 & - & $1^{\mathrm{T}}$ \\
\hline \multicolumn{4}{|c|}{$\begin{array}{l}\text { Growth with the following compounds as sole carbon and } \\
\text { energy sources: }\end{array}$} \\
\hline Acetate & 8 & + & $5,7,11,12$ \\
\hline L-Alanine & 10 & + & 4,6 \\
\hline Hydroxy-L-proline & 2 & + & $1^{\mathrm{T}}, 5$ \\
\hline L-Leucine & 8 & - & $1^{\mathrm{T}}, 2,3,5$ \\
\hline L-Lysine & 2 & + & $1^{\mathrm{T}}, 5$ \\
\hline L-Serine & 2 & + & $1^{\mathrm{T}}, 4$ \\
\hline
\end{tabular}

\footnotetext{
${ }^{a}$ As determined by the technique of Hylemon et al. (7).

${ }^{b}$ As determined by the technique of Christensen (1).

c Strains which grew at $6^{\circ} \mathrm{C}$.
} 
TABLE 3. In vitro antibiotic susceptibilities of $C$. nitrofigilis $^{a}$

\begin{tabular}{lcc}
\hline \multicolumn{1}{c}{ Antibiotic } & $\begin{array}{c}\text { Concn } \\
\text { (mg/disk) }\end{array}$ & $\begin{array}{c}\text { Widths of } \\
\text { inhibition } \\
\text { zones } \\
(\mathbf{m m})^{b}\end{array}$ \\
\hline Cephalothin & 30 & $16-27$ \\
Chloramphenicol & 30 & $8-15$ \\
Erythromycin & 15 & $9-16$ \\
Gentamicin & 10 & $13-17$ \\
Kanamycin & 30 & $12-17$ \\
Nalidixic acid & 30 & $6-15$ \\
Neomycin & 30 & $11-17$ \\
Novobiocin & 30 & 0 \\
Streptomycin & 10 & $9-15$ \\
Terramycin & 30 & $8-20$ \\
$\quad$ (oxytetracycline) & & $10-19$ \\
Tetracycline & 30 & $11-19$ \\
Tobramycin & 10 & 0 \\
Vancomycin & 30 &
\end{tabular}

${ }^{a}$ In addition, the $12 C$. nitrofigilis strains were tested for susceptibility to bacitracin, vibriostatic agent $\mathbf{0} / \mathbf{1 2 9}$, penicillin $G$, and trimethoprim in media containing the antibiotics. The highest concentrations of antibiotics at which all strains showed growth after $72 \mathrm{~h}$ of incubation at $30^{\circ} \mathrm{C}$ and the lowest concentrations at which growth was inhibited in all strains after $72 \mathrm{~h}$ were as follows: bacitracin, 256 and $1,024 \mathrm{mg} / \mathrm{ml}$, respectively; vibriostatic agent $1 / 129,150 \mathrm{mg} / \mathrm{ml}$ and not determined, respectively; penicillin G, 30 and 128 $\mathrm{mg} / \mathrm{ml}$, respectively (except for strains $1^{\mathrm{T}}$ and 6 , which grew at concentrations of $8 \mathrm{mg} / \mathrm{ml}$ but were inhibited at concentrations of $16 \mathrm{mg} / \mathrm{ml}$ ); and trimethoprim, 5 and $50 \mathrm{mg} / \mathrm{ml}$, respectively.

${ }^{b}$ Range of the widths of the inhibition zones observed for all $12 C$. nitrofigilis strains around disks after $72 \mathrm{~h}$ of incubation at $20^{\circ} \mathrm{C}$.

scribed Campylobacter species. However, several traits of these strains are unique in the genus; these include the positive urease and nitrogenase activities, pigment production from tryptophan, and the association of the organisms with plant roots. Nevertheless, these differences are insufficient to warrant exclusion of the strains from the genus in view of the numerous similar morphological and biochemical traits (15; this study).

The DNA base compositions of the nitrogenfixing Campylobacter strains, which range from 27.9 to $28.8 \mathrm{~mol} \% \mathrm{G}+\mathrm{C}$, are lower than the values obtained for other catalase-positive $\mathrm{Cam}$ pylobacter species, which range from 29.5 to 36 $\operatorname{mol} \%(20,23,24,31)$, and are also lower than the values obtained for the catalase-negative organisms Campylobacter sputorum and Campylobacter concisus, which range from 29 to 31 $\mathrm{mol} \%$ and from 34 to $38 \mathrm{~mol} \%$, respectively (20, 28). The nitrogen-fixing Campylobacter strains are further distinguished from all other previously described Campylobacter species by the unique biochemical traits described above and also by a variety of biochemical characteristics (Table 4). Unlike $C$. fetus, the nitrogen-fixing Campylobacter strains grow in the presence of $3.5 \% \mathrm{NaCl}$, do not grow anaerobically with nitrate, and are susceptible to nalidixic acid but resistant to vancomycin. The nitrogen-fixing Campylobacter strains can be distinguished from the $C$. jejuni-C. coli group by their inability to grow in the presence of $1.0 \%$ glycine, to undergo rapid coccal transformation, or to swarm on moist agar, by their ability to grow at 25 but not at $42^{\circ} \mathrm{C}$, and by their susceptibility to cephalothin. In contrast to Campylobacter faecalis, the nitrogen-fixing strains are not able to grow in the presence of $1.0 \%$ glycine or to grow anaerobically with nitrate and are able to grow at 25 but not at $42^{\circ} \mathrm{C}$. Unlike Campylobacter sputorum, the nitrogen-fixing Campylobacter strains are catalase positive, cannot grow at $42^{\circ} \mathrm{C}$, and cannot grow anaerobically with nitrate. The nitrogen-fixing Campylobacter strains differ from $C$. concisus in their positive catalase reactions, their ability to grow in $3.5 \% \mathrm{NaCl}$, their inability to grow anaerobically with nitrate, and their susceptibility to nalidixic acid. The nitrogen-fixing Campylobacter strains also differ from the strain isolated by Laanbroek et al. (11) in their ability to grow in $3.5 \% \mathrm{NaCl}$ and in their inability to grow anaerobically with nitrate. Thus the nitrogen-fixing Campylobacter strains are distinct from all previously described $\mathrm{Cam}$ pylobacter species on the basis of DNA base composition and biochemical characteristics. Therefore, these nitrogen-fixing strains of $\mathrm{Cam}$ pylobacter represent a new species, for which we propose the name Campylobacter nitrofigilis.

The obligately microaerophilic nature of $C$. nitrofigilis has potentially important implications for the study of nitrogen-fixing bacteria. The procedures used to isolate $\mathrm{N}_{2}$-fixing organisms commonly include steps involving aerobic culture (2) and, therefore, probably do not retain obligately microaerophilic organisms such as Campylobacter, as noted previously (15).

Although growth of $C$. nitrofigilis is obligately microaerophilic when oxygen is the terminal electron acceptor, both asparate and fumarate serve as terminal electron acceptors and support growth under anaerobic conditions. Nitrate does not support anaerobic growth and prevents the stimulation of anaerobic growth by aspartate and fumarate in all but the nitrate reductasenegative strains. This supports the hypothesis (15) that it is the toxic effect of the nitrite produced from nitrate reduction, rather than an inability to use nitrate as a terminal electron acceptor, that prevents stimulation of anaerobic growth by nitrate. 
TABLE 4. Characteristics useful in distinguishing $C$. nitrofigilis from other Campylobacter species $^{a}$

\begin{tabular}{|c|c|c|c|c|c|c|c|c|}
\hline Character & $\begin{array}{l}\text { C. nitro- } \\
\text { figilis }\end{array}$ & $\begin{array}{l}\text { C. fetus } \\
\text { subsp. } \\
\text { fetus }\end{array}$ & $\begin{array}{c}\text { C. fetus } \\
\text { subsp. } \\
\text { venerealis }\end{array}$ & $\begin{array}{l}\text { C. jejuni- } \\
\text { C. coli } \\
\text { group }^{b}\end{array}$ & $\begin{array}{l}\text { C. fae- } \\
\text { calis }\end{array}$ & $\begin{array}{l}\text { Campylo- } \\
\text { bacter sp. }\end{array}$ & $\begin{array}{l}\text { C. spu- } \\
\text { torum }^{b}\end{array}$ & $\begin{array}{c}\text { C. con- } \\
\text { cisus }\end{array}$ \\
\hline Nitrogenase & $t^{d}$ & - & NT & - & NT & - & NT & NT \\
\hline Catalase & + & + & + & + & + & + & - & - \\
\hline Urease & V & - & - & - & - & - & - & - \\
\hline $\mathrm{H}_{2} \mathrm{~S}$ from cysteine & + & + & $\mathrm{V}$ & + & + & - & + & + \\
\hline Pigment from tryptophan & + & - & - & - & - & - & - & NT \\
\hline \multicolumn{9}{|l|}{ Growth with: } \\
\hline $1.0 \%$ Bile & $\mathrm{V}$ & + & - & + & $\mathrm{V}$ & NT & $\mathrm{V}$ & + \\
\hline $1.0 \%$ Glycine & - & + & - & + & + & - & V & NT \\
\hline $3.5 \% \mathrm{NaCl}$ & + & - & - & - & V & - & V & - \\
\hline $0.1 \%$ Tetrazolium & - & - & - & $V^{e}$ & NT & NT & NT & NT \\
\hline \multicolumn{9}{|l|}{ Growth at: } \\
\hline $25^{\circ} \mathrm{C}$ & + & + & + & - & - & + & $\mathrm{V}$ & NT \\
\hline $42^{\circ} \mathrm{C}$ & - & - & - & + & + & - & + & NT \\
\hline Rapid coccal transformation & - & - & - & + & NT & - & NT & NT \\
\hline Hippurate hydrolysis & - & - & - & $+1-f$ & NT & NT & NT & NT \\
\hline Swarming & - & - & - & + & NT & - & NT & NT \\
\hline \multicolumn{9}{|l|}{ Susceptibility to: } \\
\hline Nalidixic acid & + & - & - & + & NT & NT & NT & - \\
\hline Cephalothin & + & + & + & - & NT & NT & NT & NT \\
\hline Vancomycin & - & + & + & - & NT & NT & NT & - \\
\hline \multicolumn{9}{|l|}{ Anaerobic growth with: } \\
\hline Nitrate & - & + & + & - & + & + & + & + \\
\hline Aspartate + fumarate & + & + & V & $\mathrm{V}$ & + & + & + & + \\
\hline $\mathrm{G}+\mathrm{C}$ content $(\mathrm{mol} \%)$ & 28.3 & 34.3 & 34.4 & $31.5 / 32.7$ & 36.6 & 41.6 & $29-31$ & $34-38$ \\
\hline
\end{tabular}

The isolation of $C$. nitrofigilis strains from high-salinity $S$. alterniflora marshes as far apart as Nova Scotia and Georgia shows that these organisms have a broad geographic range. It is not known whether the nitrogen-fixing $\mathrm{Cam}$ pylobacter strains are restricted to $S$. alterniflora marshes. However, nitrogen-fixing $\mathrm{Cam}$ pylobacter strains could not be isolated from $S$. alterniflora growing in a low-salinity marsh on Chesapeake Bay, Maryland. This, coupled with the apparent $\mathrm{NaCl}$ requirement of the organisms in vitro, suggests that these nitrogen-fixing $\mathrm{Cam}$ pylobacter strains are restricted to sites with approximately oceanic salinity. The association of $C$. nitrofigilis with the roots of a salt marsh grass contrasts with the habitat of other $\mathrm{Cam}$ pylobacter species, which commonly are associated with warm-blooded animals. This raises interesting questions about the evolutionary relationship between the nitrogen fixers and the other members of the genus.

Description of Campylobacter nitrofigilis sp. nov. $C$. nitrofigilis (ni. tro. fig' i. lis. L. n. nitrum native mineral salt, native alkali; L. v. figo to fix; L. suffix ilis ability; M.L.adj. nitrofigilis able to fix nitrogen) cells are gram-negative, curved rods 0.2 to $0.9 \mu \mathrm{m}$ in diameter and 1 to $3 \mu \mathrm{m}$ long. Coccoid bodies are found in old cultures but are not rapidly produced under aerobic conditions. Motile with a rapid corkscrew motion. Each cell possesses a single polar flagellum. Does not swarm. Chemoorganotrophic. Utilizes organic and amino acids as carbon sources, but not carbohydrates. Respiratory metabolism with oxygen as the terminal electron acceptor; anaerobic growth with aspartate and fumarate, but not with nitrate. Nitrate usually reduced to nitrite. Requires $\mathrm{NaCl}$ for growth. Grows at temperatures of 10 to $35^{\circ} \mathrm{C}$ but not at $42^{\circ} \mathrm{C}$. Catalase, oxidase, and nitrogenase positive. Some strains are urease positive. Sulfide is produced from cysteine. A brown, water-soluble pigment is produced from tryptophan. Fluorescent pigments are not produced. The base composition of the DNA is $28.3 \pm 0.1 \mathrm{~mol} \% \mathrm{G}+\mathrm{C}$ (range, 27.9 to $28.8 \mathrm{~mol} \% \mathrm{G}+\mathrm{C}$ ). Phosphatase, sulfatase, and indole negative. Does not hydrolyze esculin, casein, DNA, gelatin, hippurate, or starch. Incapable of growth with glycine $(1 \%$, $\mathrm{wt} / \mathrm{vol}$ ) or 2,3,5-triphenyltetrazolium chloride 
$(0.1 \%, \mathrm{wt} / \mathrm{vol})$. Some strains capable of growth with bile $(1 \%$, wt $/ \mathrm{vol})$. Poly- $\beta$-hydroxybutyrate not produced. Susceptible to cephalothin and nalidixic acid.

Source: isolated from roots of $S$. alterniflora taken from Conrad Beach, Nova Scotia, Cana$\mathrm{da}$, and from $S$. alterniflora roots and rootassociated sediments on Sapelo Island, Georgia.

The type strain is strain CI (= ATCC 33309).

Description of the type strain. The description of the type strain is the same as that given above for the species, with the following additions. Urease positive. Reduces nitrate to nitrite. Does not grow with bile. The base composition of the DNA is $28.0 \mathrm{~mol} \% \mathrm{G}+\mathrm{C}$ as determined by thermal denaturation and $32.1 \mathrm{~mol} \%$ as determined by buoyant density.

\section{ACKNOWLEDGMENTS}

We thank R. Christian, R. Hodson, A. MacCubbin, and E. Peele for assistance and gracious hospitality on Sapelo Island, Georgia, R. R. Colwell for the use of laboratory facilities during the initial stages of this project, I.-M. Lee for advice on the DNA procedures, and M. L. Guerinot for assistance and advice throughout.

This work was supported by the U.S. Department of Agriculture under cooperative agreement 12-24-1001-1224 with the Department of Plant Pathology, Cook College, Rutgers-The State University of New Jersey, New Brunswick.

\section{LITERATURE CITED}

1. Christensen, W. B. 1946. Urea decomposition as a means of differentiating Proteus and paracolon cultures from each other and from Salmonella and Shigella types. J. Bacteriol. 52:461-466.

2. Dobereiner, J. 1980. Forage grasses and grain crops, p. 535-555. In F. J. Begerson (ed.), Methods for evaluating biological nitrogen fixation. John Wiley \& Sons, Inc., New York.

3. Doyle, M. P. 1981. Campylobacter fetus subsp. jejuni: an old pathogen of new concern. J. Food Prot. 44:480-488.

4. Hardy, R. W. F., R. D. Holsten, E. K. Jackson, and R. C. Burns. 1968. The acetylene-ethylene assay for nitrogen fixation: laboratory and field evaluation. Plant Physiol. 43:1185-1207.

5. Harvey, S. M. 1980. Hippurate hydrolysis by Campylobacter fetus. J. Clin. Microbiol. 11:435-437.

6. Hwang, M.-N., and G. M. Ederer. 1975. Rapid hippurate hydrolysis method for presumptive identification of group B streptococci. J. Clin Microbiol. 1:114-115.

7. Hylemon, P. B., J. S. Wells, Jr., N. R. Krieg, and H. W. Jannasch. 1973. The genus Spirillum: a taxonomic study. Int. J. Syst. Bacteriol. 23:340-380.

8. Junca, P., C. Saillard, J. Tully, O. Garcia-Jurado, J.-R. Degorce-Dumas, C. Mouches, J.-C. Vignault, R. Vogel, R. McCoy, R. Whitcomb, D. Williamson, J. Latrille, and J. M. Bové. 1980. Characterisation de spiroplasmes isolés d'insectes et de fleurs de France continentale, de Corse et du Maroc. Proposition pour une classification des spiroplasmes. C. R. Acad. Sci. Ser. D 290:1209-1212.

9. Karmali, M. A., A. K. Allen, and P. C. Fleming. 1981. Differentiation of catalase-positive campylobacters with special reference to morphology. Int. J. Syst. Bacteriol. 31:64-71.
10. Karmali, M. A., and P. C. Fleming. 1979. Campylobacter enteritis. Can. Med. Assoc. J. 120:1525-1532.

11. Laanbroek, H. J., W. Kingma, and H. Veldkamp. 1977. Isolation of an aspartate-fermenting, free-living Campylobacter species. FEMS Microbiol. Lett. 1:99-102.

12. Law, J. H., and R. A. Slepecky. 1961. Assay of poly- $\beta-$ hydroxybutyric acid. J. Bacteriol. 82:33-36.

13. Lee, I.-M., and R. E. Davis. 1980. DNA homology among diverse spiroplasma strains representing several serological groups. Can J. Microbiol. 26:1356-1363.

14. Marmur, J., and P. Doty. 1962. Determination of base composition of deoxyribonucleic acid from its thermal denaturation temperature. J. Mol. Biol. 5:109-118.

15. McClung, C. R., and D. G. Patriquin. 1980. Isolation of a nitrogen-fixing Campylobacter species from the roots of Spartina alterniftora Loisel. Can. J. Microbiol. 26:881886.

15b.McCoy, R. E., H. G. Basham, and R. E. Davis. 1982. Powder puff spiroplasma: a new epiphytic mycoplasma. Microbiol. Ecol. 8:169-180.

16. McCoy, R. E., D. S. Williams, and D. L. Thomas. 1979. Isolation of mycoplasmas from flowers, p. 75-81. In Proceedings of the Republic of China-United States Cooperative Science Program Joint Seminar on Mycoplasma Diseases of Plants, Taipei, Taiwan, 27-31 March 1978. National Science Council Symposium Series, no. 1. National Science Council, Taipei, Taiwan.

17. Owen, R. J., and S. Leaper. 1981. Base composition, size and nucleotide sequence similarities of genome deoxyribonucleic acids from species of the genus Campylobacter. FEMS Microbiol. Lett. 12:395-400.

18. Razi, M. H. H., R. W. A. Park, and M. B. Skirrow. 1981. Two new tests for differentiating between strains of Campylobacter. J. Appl. Bacteriol, 50:55-57.

19. Saglio, P., M. I'Hospital, D. Laflèche, G. Dupont, J. M. Bové, J. G. Tully, and E. A. Freund. 1973. Spiroplasma citri gen. and sp. n.: a mycoplasma-like organism associated with "stubborn" disease of citrus. Int. J. Syst. Bacteriol. 23:191-204.

20. Sebald, M., and M. Véron. 1963. Teneur en bases de l'ADN et classification des vibrions. Ann. Inst. Pasteur Paris 104:897-910.

21. Skerman, V. B. D., V. McGowan and P. H. A. Sneath (ed.). 1980. Approved lists of bacterial names. Int. J. Syst. Bacteriol. 30:225-420.

22. Skirrow, M. B., and J. Benjamin. 1980. Differentiation of enteropathogenic campylobacters. J. Clin. Pathol. 33: 1122 .

23. Smibert, R. M. 1974. Campylobacter, p. 207-212. In R. E. Buchanan and N. E. Gibbons (ed.), Bergey's manual of determinative bacteriology, 8 th ed. The Williams \& Wilkins Co., Baltimore.

24. Smibert, R. M. 1978. The genus Campylobacter. Annu Rev. Microbiol. 32:673-709.

25. Stern, N. J. 1981. Campylobacter fetus subsp. jejuni: recovery methodology and isolation from lamb carcasses. J. Food Sci. 46:660-663.

26. Stern, N. J. 1981. Recovery rate of Campylobacter fetus spp. jejuni on eviscerated pork, lamb, and beef carcasses. J. Food Sci. 46:1291

27. Strength, W. J., B. Isani, D. M. Linn, F. D. Williams G. E. Vandermolen, B. E. Laughon, and N. R. Krieg. 1976. Isolation and characterization of Aquaspirillum fasciculens sp. nov., a rod-shaped, nitrogen-fixing bacterium having unusual flagella. Int. J. Syst. Bacteriol. 26:253268.

28. Tanner, A. C. R., S. Badger, C.-H. Lai, M. A. Listgarten, R. A. Visconti, and S. S. Socransky. 1981. Wolinella gen. nov., Wolinella succinogenes (Vibrio succinogenes Wolin et. al.) comb. nov., and description of Bacteroides gracilis sp. nov., Wolinella recta sp. nov., Campylobacter concisus sp. nov., and Eikenella corrodens from humans with peridontal disease. Int. J. Syst. Bacteriol. 31:432-445.

29. Tarrand, J. J., N. R. Krieg, and J. Dobereiner. 1978. A taxonomic study of the Spirillum lipoferum group, with 
descriptions of a new genus, Azospirillum gen. nov., and two species, Azospirillum lipoferum (Beijerinck) comb. nov, and Azospirillum brasilense sp. nov. Can. J. Microbiol. 24:967-980.

30. Vanhoof, R., M. P. Vanderlinden, R. Dierickx, S Lauwers, E. Yourassowsky, and J. P. Butzler, 1978. Susceptibility of Campylobacter fetus subsp. jejuni to twen- ty-nine antimicrobial agents. Antimicrob. Agents Chemother. 14:553-556.

31. Véron, M., and R. Chatelain. 1973. Taxonomic study of the genus Campylobacter Sebald and Véron and designation of the neotype strain for the type species, Campylobacter fetus (Smith and Taylor) Sebald and Véron. Int. J. Syst. Bacteriol. 23:122-134. 